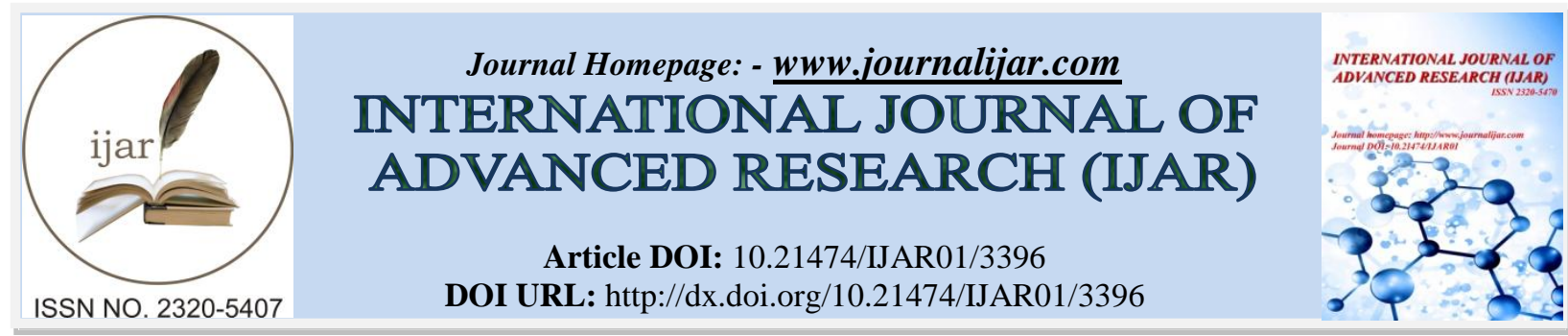

RESEARCH ARTICLE

\title{
A CRITIAL ANALYSIS OF IMPRINTS OF NEOTECTONISAM IN SUKTA SUB -BASIN, PARTS OF NARMADA RIFT VALLEY, DISTRICT KHANDWA M.P.INDIA.
}

Dr. A. A. Khan ${ }^{1}$ and Rajeev Gandhi Proud yogiki Maha vidyalaya ${ }^{2}$.

1. Ex. Director, Geological Survey of India.

2. Director, Bhopal-462042, M.P India.

\section{Manuscript Info}

Manuscript History

Received: 14 December 2016

Final Accepted: 19 January 2017

Published: February 2017

\section{Abstract}

The geological geomorphological and Neotectonic studies of parts of Khandwa district Madhya Pradesh were carried out with the aid of Air photos between latitude $21^{\circ} 30^{\prime \prime} 00$ to $21^{\circ} 45^{\prime} 00$ and longilude $76^{\circ} 15^{\prime} 00$ to $76^{\circ} 30^{\prime}$ in parts of Survey of India Sheet No. 55Cl6 and an area about 720 sq.km. was covered by photo interpretation.

eologically the area comprised of Deccan trap and Quaternary sediment. The Deccan trap complex comprised of fifteen basaltic lava flows between 250 to $600 \mathrm{~m}$ above m.s.l. These lava flows constitute two formations viz. Khandwa formation (Nimar Group) consisting of six lava sheets between elevation of 250 to $360 \mathrm{~m}$ above m.s.l. and Asirgarh formation (Satpura Group) Consisting of nine lava sheets between 360 to $600 \mathrm{~m}$ above m.s.l. The exposed thickness of these lava flows is about $190 \mathrm{~m}$.

The Quaternary deposits are represented by the sediments of two domain viz the sediments of present domain of Sukta and sediments of paleo domain of Sukta. These sediment predominantly comprised of sand, clay, silt and rock gravel. These deposits in the area are viz thin and occur as relict terraces and flood plain deposits, the average exposed thickness is about $3 \mathrm{~m}$.

Geomorphologically the area comprised of nine surfaces each surface is characterized by distinct morphogenetic expression elevation, drainage, pedogenetic characters, slope elements and land use pattern. These surfaces are confined between 280 to $480 \mathrm{~m}$ above m.s.l. These surfaces in increasing antiquity are Quaternary terraces (280 to $300 \mathrm{~m}$ ), Mordar surface (300 m), Sarala surface (320 m), Khadar surface (340 $\mathrm{m})$, Borgaon surface $(360 \mathrm{~m})$, Jalandhar surface $(400 \mathrm{~m})$, Sarai surface (440 m), Gularpani (SE) $460 \mathrm{~m}$ and Gularpani (SW) (460-80 m). The morphogenetic expression of these surface has been appreciably by defaced by Neo-seismic events occurred in recent past along the network of lineaments traversing the area. The Sukta lineament trending in NE-SW, direction traverse across Mardar, Sarala, Khodar, Borgaon surfaces display selective entrustment and bear the imprints of Neotectonism in the area.

The other geomorphic features and land form elements association with the area are flood plain point bar, low level terraces, channel braids. Linear scarp, curvilinear scarp, knee shaped band, scree, re-treating 
scarp and relict terraces. Besides the area is associated with the morpho-tectonic elements viz perennial channel segments, impersistent and partly internal drainage, knee shaped channel band, linear scarps and rock cut terraces.

The study revealed the presence of five major lineament pattern in the area viz i) NE-SW, ii) NW-SE, iii) NNE-SSW to N-S, iv) NNW-WSW to $\mathrm{E}-\mathrm{W}$. The relative percentage of occurrence of these linear elements in different pattern is $29.7 \%, 23.4 \%, 23.4 \%, 14.1 \%$ and $9.4 \%$ respectively. The analysis of relative intensely of these lineaments reveal that major, intermediate lineament exhibit anisotropic intensity and minor elements isotropic intensity.

The Sukta is the major stream which drains across the northern part of area. Its course is controlled by NE-SW trending lineament named as Sukta lineament. It appears to be basement lineament and some movement has been taken place along this lineament in recent past. It is evident by morphogenetic manifestation of the area and imprints of Neotectonism along this lineament. A another prominent lineament which traverses between Sultanpur and Bodgaon along Moti Nala, display occurrences of hanging and impersistent drainage which often truncate against this lineament. It indicates the readjustment of base level of drainage system perhaps due to recent movement along the NE-SW trending liniment in the area. The imprints and signature of such events are documented by these first and second order steams being their sensitive and infant nature and their quick response to such events.

The Lakhauri NW-SE trending lineament and associated fabrics bears the imprints of Neotectonism and indicate some movement in the area. The other lineament trending in NNW-SSE to N-S, NNE -SSE to N-S are associated with master joints and fracture and devoid of any significant signature of Neotectonic activity. The ENE -WSW to E-W in the area represent $9.4 \%$ of total lineament density of the area and bears some imprints of neotectonic activity east of Arud

The study of morphogenetic expression and analysis of imprints of neaotectonisam and overall morpho- tectonic manifestation of the area coupled with available data indicate that NE-SW trending set of lineament are active and some movement has been taken place in recent past in the area , as such the area appears to be active and prone to Neoseismic movements.

The critical analysis of data and application of keys combined with stratigraphic studies provide significant information to constrain timing and intensity and degree of movement of Sukta fault as inbuilt component of SONATA Lineament in the central western Narmada valley an important ENE-WSW-trending tectonic element responsible for the current interpolate seismicity being experienced in the central part of the Indian plate. The tectonic movements along the NSF during Late Pleistocene and Holocene have resulted three river terraces (NT_1 to NT_3) in Narmada valley which are in conformity of three major phases of tectonic movements in a compressive stress regimes recorded along the NSF: slow synsedimentary subsidence of the basin during Late Pleistocene due to differential movement, followed by inversion of the basin during the Holocene marked by differential uplift along the NSF. The study suggests that the inversion of the basin is in response to the significant increase in the intensity of compressive stresses in the Indian plate mainly during the Early Holocene. The occurrences of geomorphic land form elements and features, rock cut terraces, linear, scarp curvilinear scrap knee shaped channel band ad segments, 
perennial channel segments, impersistent and partly internal drainage, and rock scar and plantation surfaces which are the resultant elements of tectonic movement related NSF fault to wards lat Holocene. The present incisive drainage and recent seismic activity along Sukta lineament indicate that the compressive stresses continue to accumulate along the NSF due to continued northward movement of the Indian plate.

Copy Right, IJAR, 2017,. All rights reserved.

\section{Introduction:-}

The Geological and Geomorphological studies in parts of Khandwa district M.P. in Survey of India top sheet No. $55 \mathrm{C} / 6$ was carried out by the author with the aid of Air photos (scale 1:50000), and an area about 720 sq.km was covered by photo interpretation. The area is located south of the Khandwa and bounded by latitute $21^{\circ} 30$ ' $00^{\text {" ' and }}$ $21^{\circ} 45^{\prime}$ '00" and longitudes $76^{\circ} 5$ ' $00^{\prime}$ " to $76^{\circ} 30$ ' $00^{\prime}$ " $\mathrm{E}$ in top sheet Nos. $55 \mathrm{C} / 6$. The district headquarter Khandwa is well connected by State Highways and is a major railhead for broad and meter gauge sections of Central Railways. The area lies $10 \mathrm{~km}$. South of Khandwa and is approachable by all weather roads. Khandwa - Singot - Borgaon Burhanpur road diagonally passes through the areas. The interior part of the area is well connected by network of forest roads. The Khandwa - Bombay broad gauge of Central Railways passes through the Central part of the area with Dongargaon Khodar and Bagmer are important rail head in the area. The Ajmer - Khandwa - Kachigoda meter gauge line passes through the north - eastern part of the area with Mordar is main rail head. (Plate No_1)

The area of study consists of two Physiography units viz the Nimar Plain (Narmada Valley) in the north and Satpura upland in south. The Nimar plain is characterized by a moderately updulating topography with a few low lying flat topped hills. The Satpura up land in South is characterized by the ENE-WSW to E-W trending chain of higly dissected and terraced plateau extending from Bankri on the west to Dahinala on the east. The minimum elevation of the area is $280 \mathrm{~m}$. maximum elevation of is $480 \mathrm{~m}$. above m.s.1.

The area is characterized by sub dendritic to sub-parallel drainage pattern. The Satpura upland form the major water divide for northerly and southerly flowing streams of the area draining into Narmada and Tapti river respectively. Bham river flowing in a westerly and northwesterly direction along with its numerous northerly flowing tributaries constitute the major drainage in the eastern part of the area. The western and north central part of the area is chiefly drained by northerly flowing Sukta Nadi and Lakhauri Nadi. The southern and south eastern part of the area is drained by Amadnagar and Pandhar Nadi which ultimately join Tapti river in the north.

\section{Previous Work:-}

The area is covered by basaltic lava flows, Sharma \& Yadava (1984), Yadava \& Kandpal (1985) studied various aspects of lava flows their petro-chemistry, mineralogy and built up the stratigraphy of the area.

\section{Present Work:-}

The present work is based of data acquired ad accrued from satellite imagery (IRS) of optical signatures of micro neosiesmic episodes of the area related with recent movements along the lineament fabrics of Earthquake prone area . The keys of Geomorphology and morphogenetic manifestation are applied and used in the west central segments of the SONATA LIEAMENT ZONE to trace and \& analyze the imprints of neotectonism. The results of data of imprints in terms of optical signatures and landform configuration acquired and accrued both in laboratory and from ground, its synthesis \& analysis and modeling by computer has been presented for the first time

\section{Geological Setup:-}

The area studied is underlain by the theolitic basaltic lava flows belonging to Deccan Trap complex. These flows are confined between altilude of $245 \mathrm{~m}$ and $485 \mathrm{~m}$ above $\mathrm{m} . \mathrm{s} .1$. The average thickness of these lava sheets is about $190 \mathrm{~m}$. A total of 15 basaltic lava flows are reported in the area by Sharma \& Yadava (1984), and Yadava and Kandpal (1985). In general these are fine grained, massive hard and compact and non Porphyritic to sparsely porphyritic and some moderately to highly porphyritic in nature. These flows generally exhibit 'Aa' characters. The thickness of individual flow varies from 20 to $40 \mathrm{~m}$. These lava flows are divided into two formation designated as Khandwa formation and Asirgarh formation of Nimar and Satpura Group reported by Sharma \& Yadava (1984). The Geological and lithostratigraphic sequence of the area is given in Table No.1 below:- 
Table No.1:- Geological Succession of the area OSI

Sheet No. 55C/6

Age Group Formation General Characters

Holocene Quaternary sediments of Sukta

Rock Gravels Sand, Silt and Clay

and its Tributaries

(265-270 m) above m.s.l.

Asirgarh for mation

Upper (Satpura a Group)

(360 $\mathrm{m}$ to $600 \mathrm{~m}$ above m.s.1.)

Cretaceous

Some of flows contain mega cryst

to lower

Are separted by red bole weathered

Eocene

Khandwa formation

(Nimar Group)

(250 to $360 \mathrm{~m}$ above m.s.l)

Flows non-porphyratic. These flows

Are separated by red bole intratra-

ppen beds etc.
Nine basaltic lava flows vesicular amygdular

Mostly with fragmentary top. The

The most of flows are "Aa" type,

Unit at places. The individual flows

Surface and intertrappean zone.

Six basaltic lava flows highly vesicular

mygdular fragmentary and palaeo weathered top zone. Some of the

Table No .2:- Salient Features Of Quaternary \& Prequaternary Surfaces In Sukta Sub-Basin Locality: KHIRGAON

\begin{tabular}{|c|c|c|c|c|c|c|c|}
\hline & River bad & T-o & T-1 & T-2- & PQS II-IV & $\begin{array}{l}\text { PQS IV- } \\
\text { VI }\end{array}$ & $\begin{array}{l}\text { PQSVI- } \\
\text { VIII }\end{array}$ \\
\hline \multicolumn{5}{|l|}{ Age } & \multicolumn{3}{|c|}{ HOLOCENE } \\
\hline $\begin{array}{l}\text { Elevation above } \\
\text { MSL (m) }\end{array}$ & 270 & 275 & 280 & 300 & 300-360- & $360-420$ & $\begin{array}{l}420-480 \\
\text { Planation } \\
\text { surfaces } \\
\text { rock Scar }\end{array}$ \\
\hline $\begin{array}{l}\text { Geomorphic } \\
\text { break }(\mathbf{m})\end{array}$ & 0.00 & $\begin{array}{l}5.00 \\
\text { Alluvial } \\
\text { Face }\end{array}$ & $\begin{array}{l}5.00 \\
\text { Alluvial } \\
\text { Bluff } \\
\text { Section } \\
\text { Steep } \\
\text { Alluvial } \\
\text { face }\end{array}$ & $\begin{array}{l}20.00 \\
\text { Steep } \\
\text { Alluvial \& } \\
\text { Composite } \\
\text { Rock Face }\end{array}$ & $\begin{array}{l}\text { 60.00 } \\
\text { Plantation } \\
\text { surfaces } \\
\text { Rock cut } \\
\text { Terraces } \\
\text { rock Scar } \\
\text { Rock } \\
\text { Face }\end{array}$ & $\begin{array}{l}\text { 80.00 } \\
\text { Plantation } \\
\text { surfaces / } \\
\text { dissection } \\
\text { Rock cut } \\
\text { Terraces } \\
\text { rock Scar } \\
\text { Rock } \\
\text { Face }\end{array}$ & $\begin{array}{l}\text { 60.00 } \\
\text { Plantation } \\
\text { surfaces } \\
\text { Rock cut } \\
\text { Terraces } \\
\text { rock Scar } \\
\text { Composite } \\
\text { Rock Face }\end{array}$ \\
\hline $\begin{array}{l}\text { Elevation above } \\
\text { RB (m) }\end{array}$ & $\begin{array}{l}\text { 0.00 } \\
\text { River bad } \\
\text { Channel, } \\
\text { Point Bar, } \\
\text { Side Bar }\end{array}$ & $\begin{array}{l}5.00 \\
\text { Rock } \\
\text { Face and } \\
\text { Alluvial } \\
\text { Bluff }\end{array}$ & $\begin{array}{l}\text { 10..00 } \\
\text { Rock } \\
\text { Face } \\
\text { and } \\
\text { Alluvial } \\
\text { Bluff } \\
\end{array}$ & $\begin{array}{l}20 . .00 \\
\text { Alluvial } \\
\text { Bluff } \\
\text { Rock Face }\end{array}$ & $\begin{array}{l}40.00 \\
\text { Rock cut } \\
\text { Face }\end{array}$ & $\begin{array}{l}46.00 \\
\text { Rock } \\
\text { Face }\end{array}$ & $\begin{array}{l}51.00 \\
\text { Rock cut } \\
\text { faces rock } \\
\text { Scar }\end{array}$ \\
\hline Slope & \multicolumn{2}{|c|}{$\begin{array}{ll}------T o w a r d s & \text { North } \\
\text { west ------ } & \\
\end{array}$} & & \multicolumn{2}{|c|}{-------Towards North - } & \multicolumn{2}{|c|}{------'Towards North } \\
\hline Nature of surface & \multicolumn{4}{|c|}{$\begin{array}{l}\text {------Depositional, Cresent shape elongated ---- } \\
\text { - Erosional ............... }\end{array}$} & \multicolumn{3}{|c|}{$\begin{array}{l}\text { Rock cyut terraces and Rock scar -- } \\
\text {-----Erosional ---Lieanr scar line --. } \\
--\end{array}$} \\
\hline
\end{tabular}




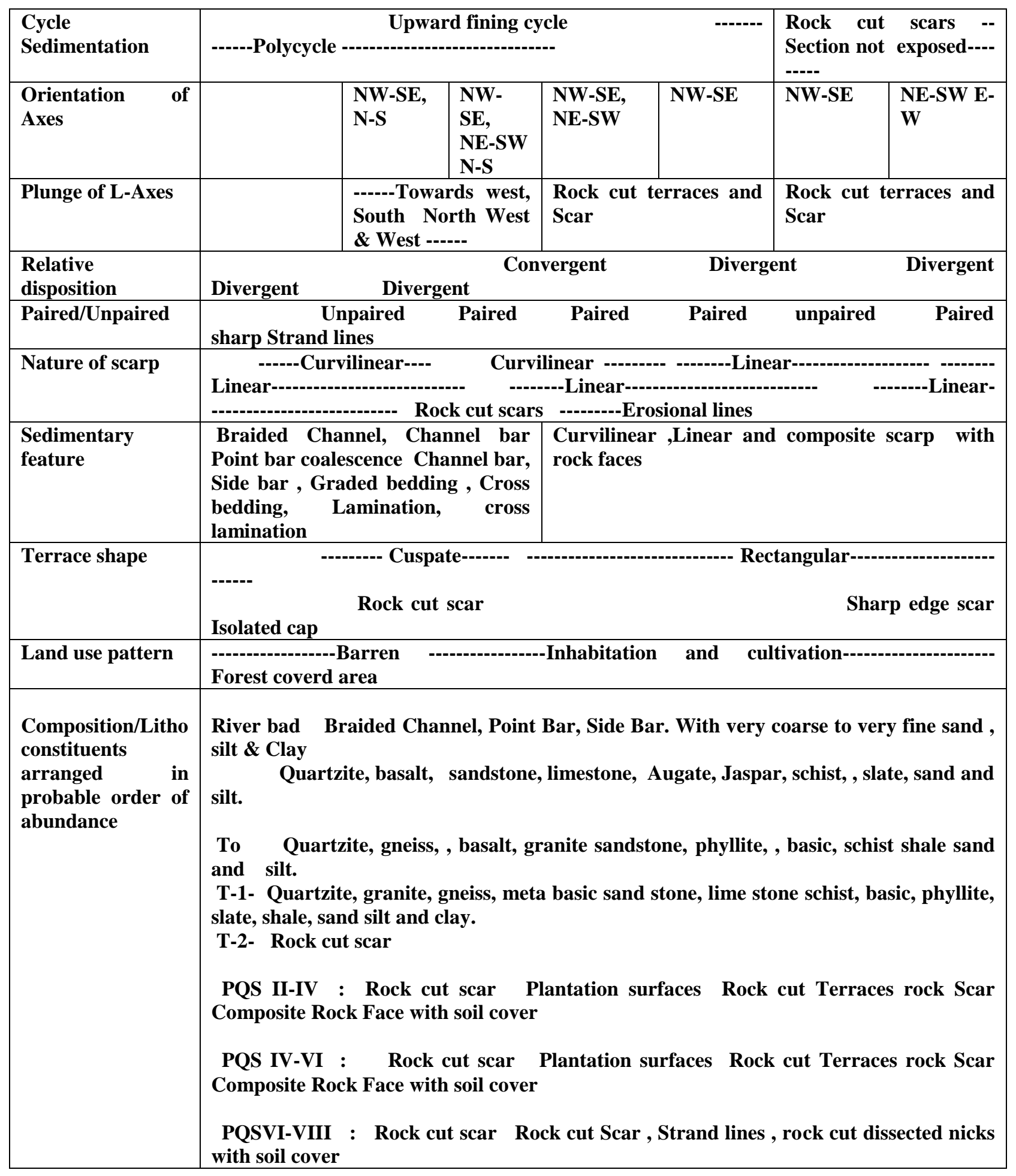


Table no. 3:- salient features of quaternary \& prequaternary surfaces in sukta sub-basin Locality: BADGAON

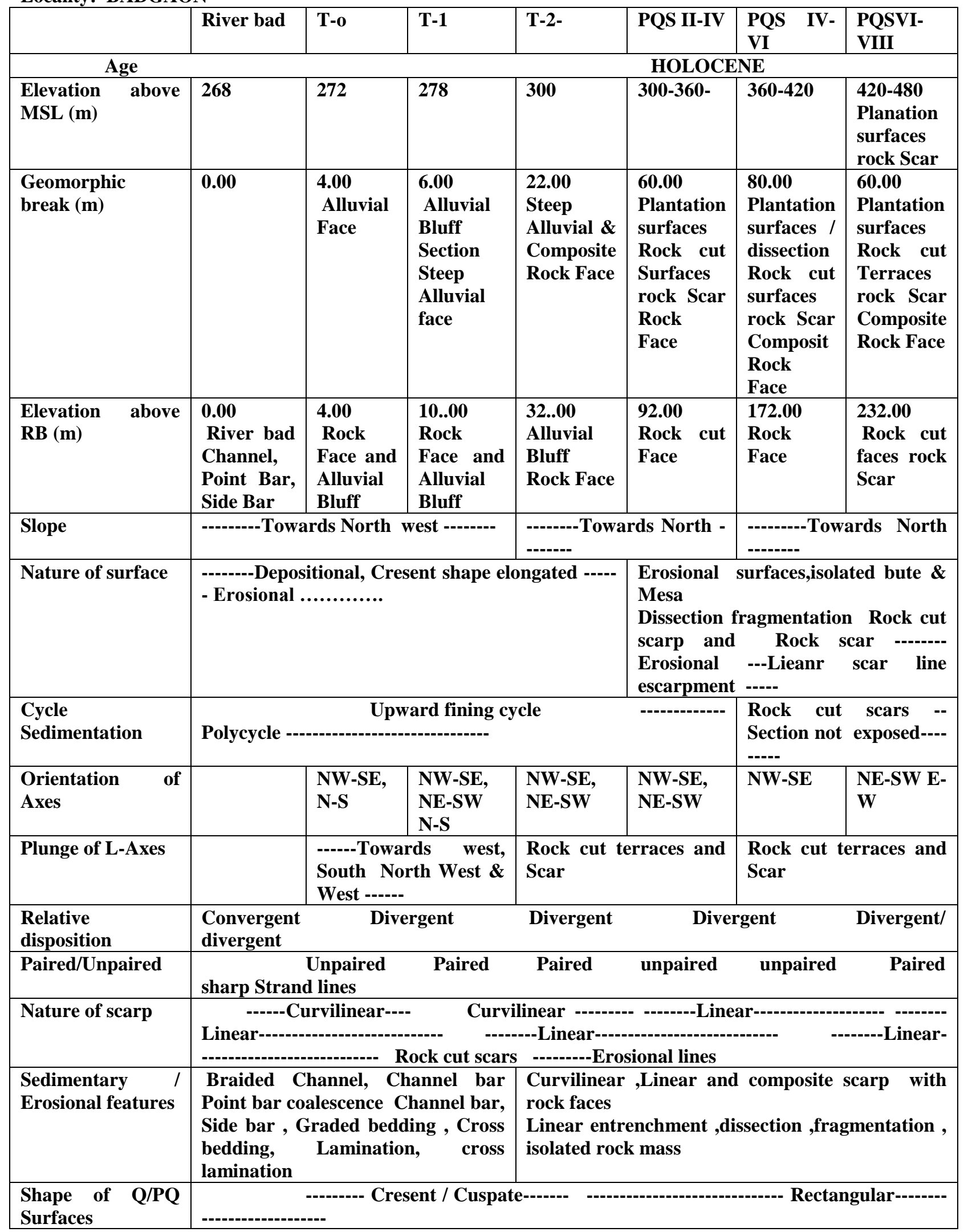




\begin{tabular}{|c|c|}
\hline & Sharp edge scar \\
\hline Land use pattern & 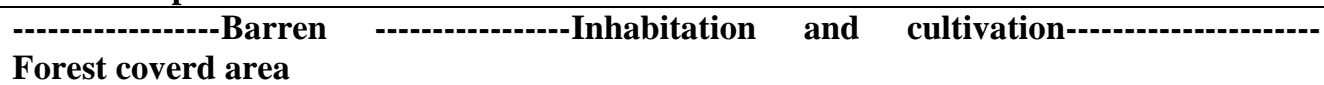 \\
\hline $\begin{array}{l}\text { Composition/Litho } \\
\text { constituents } \\
\text { arranged in } \\
\text { probable order of } \\
\text { abundance }\end{array}$ & $\begin{array}{l}\text { River bad: Braided Channel, Point Bar, Side Bar. With very coarse to very fine sand, } \\
\text { silt \& Clay } \\
\text { basalt, sandstone, limestone, Augate, Jaspar, , sand and silt. } \\
\text { T-o Quartzite, gneiss, , basalt, granite sandstone, phyllite, , basic, schist shale sand } \\
\text { and silt. } \\
\text { T-1- Quartzite, granite, gneiss, meta basic sand stone, lime stone schist, basic, phyllite, } \\
\text { slate, shale, sand silt and clay. } \\
\text { T-2- Rock cut scar } \\
\text { PQS II-IV : Rock cut scar Plantation surfaces Rock cut Terraces rock Scar } \\
\text { Composite Rock Face soil cover } \\
\text { PQS IV-VI : Rock cut scar Plantation surfaces Rock cut Terraces rock Scar } \\
\text { Composite Rock Face with soil cover } \\
\text { PQSVI-VIII : Rock cut scar Rock cut Scar, Strand lines, rock cut dissected nicks } \\
\text { with soil cover }\end{array}$ \\
\hline
\end{tabular}

Table no. 4:- salient features of quaternary \& prequaternary surfaces in sukta sub-basin Locality: SARLA

\begin{tabular}{|c|c|c|c|c|c|c|c|}
\hline & River bad & T-o & T-1 & T-2- & PQS II-IV & PQS IV-VI & $\begin{array}{l}\text { PQSVI- } \\
\text { VIII }\end{array}$ \\
\hline \multicolumn{4}{|l|}{ Age } & \multicolumn{4}{|c|}{ HOLOCENE } \\
\hline $\begin{array}{l}\text { Elevation above } \\
\text { MSL (m) }\end{array}$ & 265 & 270 & 275 & 300 & 300-360- & $360-420$ & $\begin{array}{l}420-480 \\
\text { Planation } \\
\text { surfaces } \\
\text { rock Scar }\end{array}$ \\
\hline $\begin{array}{l}\text { Geomorphic break } \\
\text { (m) }\end{array}$ & 0.00 & $\begin{array}{l}5.00 \\
\text { Alluvial } \\
\text { Face }\end{array}$ & $\begin{array}{l}\text { 5.00 } \\
\text { Alluvial } \\
\text { Bluff } \\
\text { Section } \\
\text { Steep } \\
\text { Alluvial } \\
\text { face }\end{array}$ & $\begin{array}{l}25.00 \\
\text { Steep } \\
\text { Alluvial \& } \\
\text { Composite } \\
\text { Rock Face }\end{array}$ & $\begin{array}{l}\text { 60.00 } \\
\text { Plantation } \\
\text { surfaces } \\
\text { Rock cut } \\
\text { Surfaces } \\
\text { rock Scar } \\
\text { Rock Face }\end{array}$ & \begin{tabular}{|l|}
80.00 \\
Plantation \\
surfaces / \\
dissection \\
Rock cut \\
surfaces \\
rock Scar \\
Composit \\
Rock Face \\
\end{tabular} & $\begin{array}{l}\text { 60.00 } \\
\text { Plantation } \\
\text { surfaces } \\
\text { Rock cut } \\
\text { Terraces } \\
\text { rock Scar } \\
\text { Composite } \\
\text { Rock Face }\end{array}$ \\
\hline $\begin{array}{l}\text { Elevation above } \\
\text { RB }(\mathbf{m})\end{array}$ & $\begin{array}{l}\text { 0.00 } \\
\text { River } \\
\text { bad } \\
\text { Channel, } \\
\text { Point Bar, } \\
\text { Side Bar }\end{array}$ & $\begin{array}{l}5.00 \\
\text { Rock } \\
\text { Face } \\
\text { and } \\
\text { Alluvial } \\
\text { Bluff }\end{array}$ & $\begin{array}{l}10 . .00 \\
\text { Rock } \\
\text { Face and } \\
\text { Alluvial } \\
\text { Bluff }\end{array}$ & $\begin{array}{l}35 . .00 \\
\text { Alluvial } \\
\text { Bluff Rock } \\
\text { Face }\end{array}$ & $\begin{array}{ll}95.00 & \\
\text { Rock cut } \\
\text { Face }\end{array}$ & \begin{tabular}{|l|}
175.00 \\
Rock Face
\end{tabular} & $\begin{array}{l}235.00 \\
\text { Rock cut } \\
\text { faces rock } \\
\text { Scar }\end{array}$ \\
\hline Slope & \multicolumn{3}{|c|}{------Towards North west ----- } & \multicolumn{2}{|c|}{ 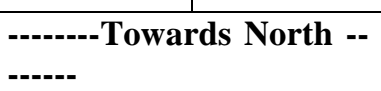 } & \multicolumn{2}{|c|}{$\begin{array}{l}\text {--------Towards North -- } \\
-----\end{array}$} \\
\hline Nature of surface & \multicolumn{4}{|c|}{$\begin{array}{l}----- \text { Erosional \& depositional I, Cresent } \\
\text { shape elongated -.--- Erosional .............. }\end{array}$} & \multicolumn{3}{|c|}{$\begin{array}{l}\text { Erosional surfaces,isolated bute \& } \\
\text { Mesa } \\
\text { Dissection fragmentation Rock cut } \\
\text { scarp and Rock scar -------Erosional }\end{array}$} \\
\hline
\end{tabular}




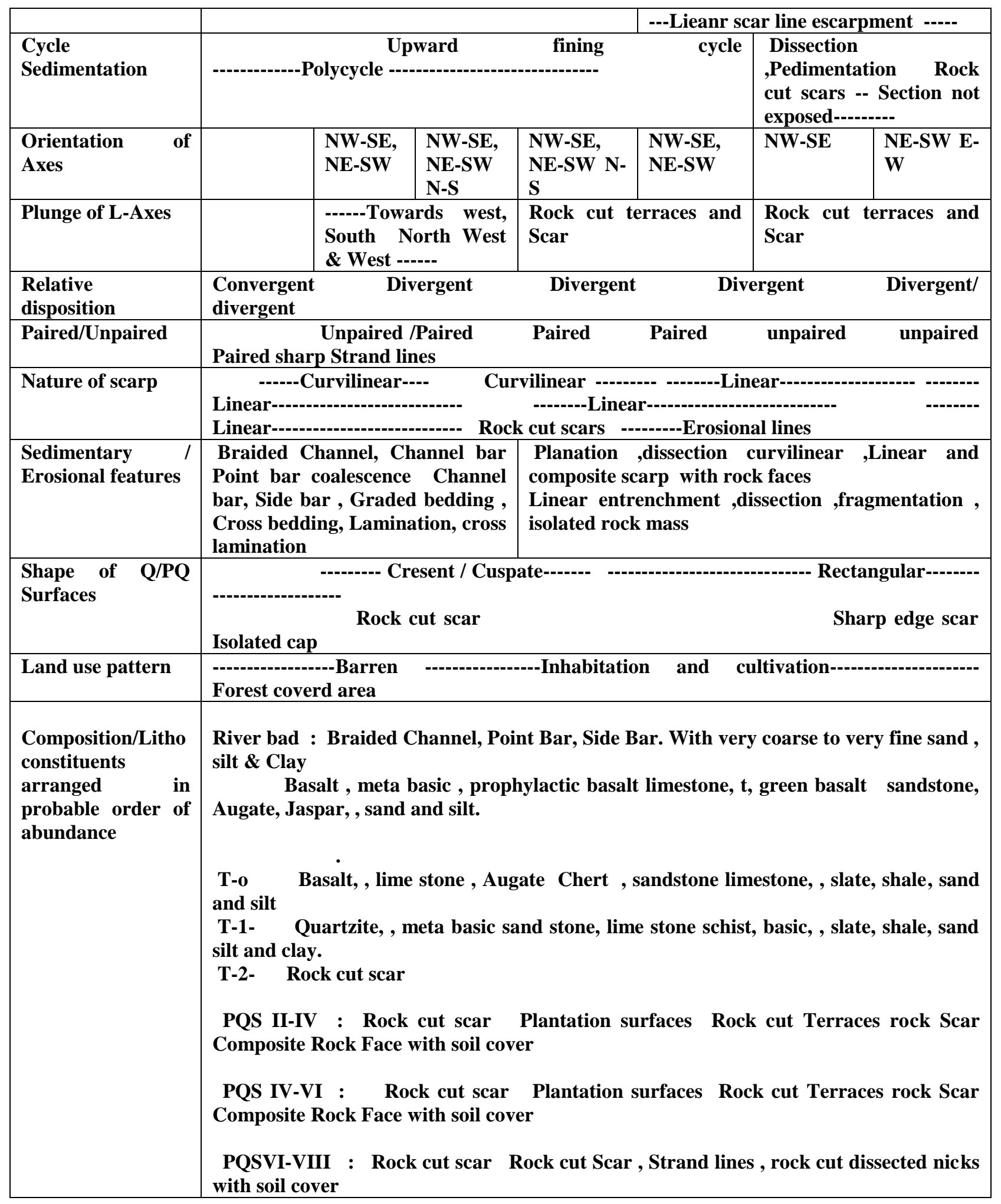


Table no. 5:- salient features of quaternary \& prequaternary surfaces in sukta sub-basin Locality: KHIRALA

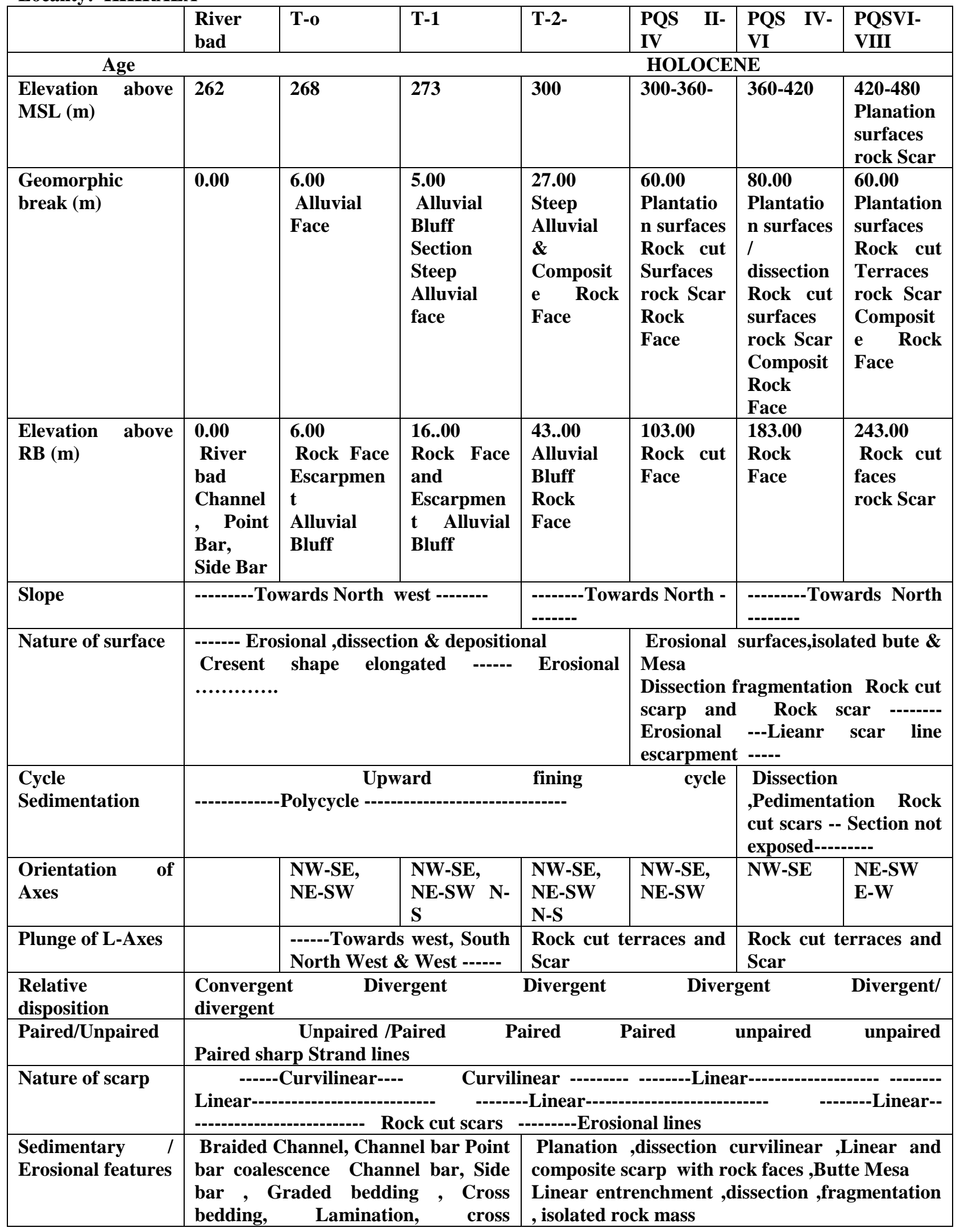




\begin{tabular}{|c|c|}
\hline & Imination \\
\hline $\begin{array}{l}\text { Shape of } \mathrm{Q} / \mathrm{PQ} \\
\text { Surfaces }\end{array}$ & 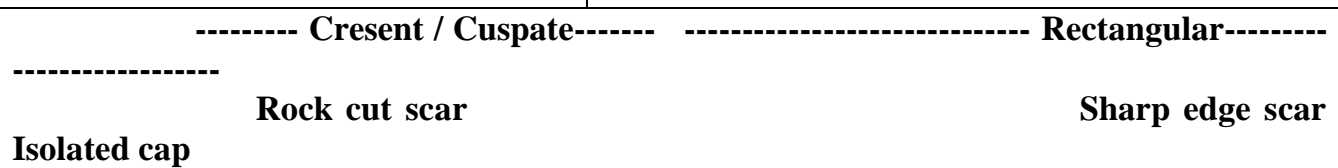 \\
\hline Land use pattern & 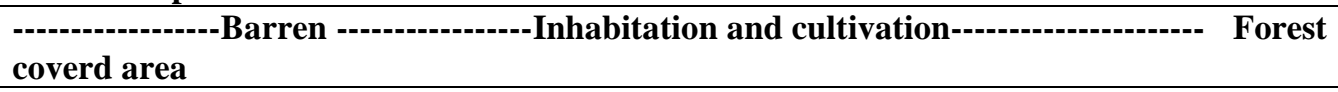 \\
\hline $\begin{array}{l}\text { Composition/Lith } \\
\text { o constituents } \\
\text { arranged in } \\
\text { probable order of } \\
\text { abundance }\end{array}$ & $\begin{array}{l}\text { River bad Braided Channel, Point Bar, Side Bar. With very coarse to very fine sand, } \\
\text { silt \& Clay. } \quad \text { prophylactic basalt, limestone, basalt, green basalt sandstone, Augate, } \\
\text { Jaspar,Chart, sand and silt. } \\
\text { T-o Basalt, , Augate Chert, sandstone limestone, slate, shale, sand and silt } \\
\text { T-1- Quartzite, meta basic sand stone, lime stone meta basalt, basic, , slate, , sand } \\
\text { silt and clay. } \\
\text { T-2- Rock cut scar } \\
\text { PQS II-IV : Rock cut scar Plantation surfaces Rock cut Terraces rock Scar } \\
\text { Composite Rock Face with soil cover } \\
\text { PQS IV-VI : Rock cut scar Plantation surfaces Rock cut Terraces rock Scar } \\
\text { Composite Rock Face with soil cover } \\
\text { PQSVI-VIII : Rock cut scar Rock cut Scar, Strand lines, rock cut dissected nicks } \\
\text { with soil cover }\end{array}$ \\
\hline
\end{tabular}

Table no. 6:- salient features of quaternary \& prequaternary surfaces in sukta sub-basin Locality: KOTRA

\begin{tabular}{|c|c|c|c|c|c|c|c|}
\hline & River bad & T-o & T-1 & T-2- & PQS II-IV & PQS IV-VI & $\begin{array}{l}\text { PQSVI- } \\
\text { VIII }\end{array}$ \\
\hline \multicolumn{4}{|l|}{ Age } & \multicolumn{4}{|c|}{ HOLOCENE } \\
\hline $\begin{array}{l}\text { Elavation above } \\
\text { MSL (m) }\end{array}$ & 269 & 273 & 279 & 300 & 300-360- & $360-420$ & $\begin{array}{l}\text { 420-480 } \\
\text { Planation } \\
\text { surfaces } \\
\text { rock Scar }\end{array}$ \\
\hline $\begin{array}{l}\text { Geomorphic break } \\
\text { (m) }\end{array}$ & 0.00 & $\begin{array}{l}4.00 \\
\text { Alluvial } \\
\text { Face }\end{array}$ & $\begin{array}{l}\mathbf{6 . 0 0} \\
\text { Alluvial } \\
\text { Bluff } \\
\text { Section } \\
\text { Steep } \\
\text { Alluvial } \\
\text { face }\end{array}$ & $\begin{array}{l}20.00 \\
\text { Steep } \\
\text { Alluvial \& } \\
\text { Composite } \\
\text { Rock Face }\end{array}$ & $\begin{array}{l}60.00 \\
\text { Plantation } \\
\text { surfaces } \\
\text { Rock cut } \\
\text { Terraces } \\
\text { rock Scar } \\
\text { Rock Face }\end{array}$ & $\begin{array}{l}80.00 \\
\text { Plantation } \\
\text { surfaces / } \\
\text { dissection } \\
\text { Rock cut } \\
\text { Terraces } \\
\text { rock Scar } \\
\text { Rock Face }\end{array}$ & $\begin{array}{l}60.00 \\
\text { Plantation } \\
\text { surfaces } \\
\text { Rock cut } \\
\text { Terraces } \\
\text { rock Scar } \\
\text { Composite } \\
\text { Rock Face }\end{array}$ \\
\hline $\begin{array}{l}\text { Elavation above } \\
\text { RB }(\mathbf{m})\end{array}$ & $\begin{array}{l}\text { 0.00 } \\
\text { River } \\
\text { bad } \\
\text { Channel, } \\
\text { Point } \\
\text { Bar, Side } \\
\text { Bar }\end{array}$ & $\begin{array}{l}4.00 \\
\text { Rock } \\
\text { Face } \\
\text { and } \\
\text { Alluvial } \\
\text { Bluff }\end{array}$ & $\begin{array}{l}\text { 10..00 } \\
\text { Rock } \\
\text { Face and } \\
\text { Alluvial } \\
\text { Bluff }\end{array}$ & $\begin{array}{l}\text { 30..00 } \\
\text { Alluvial } \\
\text { Bluff Rock } \\
\text { Face }\end{array}$ & $\begin{array}{l}90.00 \\
\text { Rock cut } \\
\text { Face }\end{array}$ & $\begin{array}{l}\text { 150.00 } \\
\text { Rock Face }\end{array}$ & $\begin{array}{l}210.00 \\
\text { Rock cut } \\
\text { faces rock } \\
\text { Scar }\end{array}$ \\
\hline Slope & \multicolumn{3}{|c|}{------Towards North west ------ } & \multicolumn{2}{|c|}{$\begin{array}{l}\text {-------Towards North -- } \\
----\end{array}$} & \multicolumn{2}{|c|}{-------'Towards North -- } \\
\hline Nature of surface & \multicolumn{4}{|c|}{$\begin{array}{l}\text {-------Depositional, Cresent shape elongated --- } \\
\text {--- Errosional .............. }\end{array}$} & \multicolumn{3}{|c|}{$\begin{array}{l}\text { Rock cyut terraces and Rock scar ---. } \\
\text {----Erosionall ---Lieanr scar line ----- }\end{array}$} \\
\hline
\end{tabular}




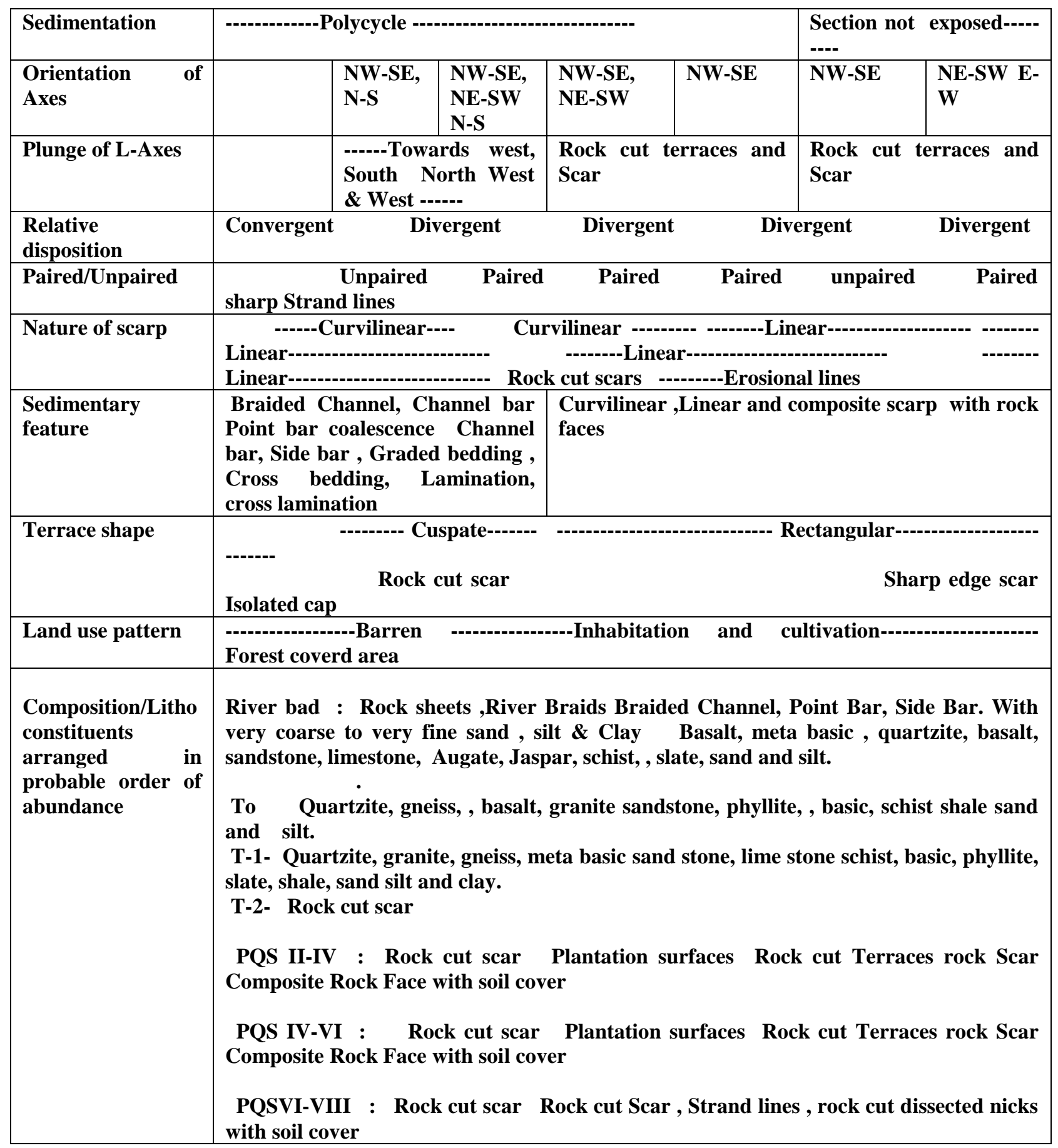

Khandwa Formation:-

(Nimar Group)

The Khandwa formation consists of six lava flows identified between elevation of 250 to $360 \mathrm{~m}$ above m.s.l. The average exposed thickness of this formation is about $110 \mathrm{~m}$. in the area. The lava sheets of this formation are generally highly vesicular, amygdule, and sparsely porphyritic in nature. The individual flows are fine to medium grained hard compact, at places these flows are separated either by red bole, weathered zone or inter-trappean bed. This formation is exposed in the northern part of the area. 


\section{Asirgarh Formation:- \\ (Satpura Group)}

The Asirgarh formation consists of nine lava flows identified between elevation of 360 to $600 \mathrm{~m}$ above m.s.l. The average exposed thickness of this formation is about $240 \mathrm{~m}$. The lava flows of this formation are mostly vesicular, amygdular and are "A" type. The some of lava sheet contain mega cryst unit of feldspar. These are generally fine to medium grained hard compact and joined in nature. The vesicular unit is mostly spherical and filled with secondary silica and zeolite. These flows are either separated by red bole or inter-trappean bed. This formation is exposed in the southern part of the area.

\section{Quaternary Sediments:-}

The quaternary sediments and residual soil have occupied the northern part opf the area of study. The quaternary deposits comprised of sediment of two domains, viz the sediment of present domain of Sukta and sediments of Paleo, domain of Sukta. The former constitutes the sediment of active flood plain facies and represented by silt, clay and rock gravel. It is restricted to the narrow valley along Sukta and its tributaries at an elevation of 265 to $280 \mathrm{~m}$ above m.s.l. The average thickness of sediment is about $2.5 \mathrm{~m}$. The later comprised of sediment of flood plain facies of paleo-domain of Sukta predominated by clay, slit sand and rock fragments. These sediments form the quaternary terraces which are ill due to neotectonic activity in the area preserved and confined within the meandering loop of Sukta river.

These terraces are identified at an elevation of 280-340-300 m above m.s.l. and represent the former level of valley floor.

The northern plateau area is occupied by black cotton soil of residual nature developed on basaltic terrain. The thickness of soil varies from 2.5 to $6 \mathrm{~m}$ and average thickness is about $4.5 \mathrm{~m}$. The soil thickness generally increases towards north. (Plate No._2)

\section{Geomorphological Set Up:-}

In Regional morphogenetic analysis of Sukta sub-basin were undertaken by Remote sensing techniques to decipher and trace the very process and events and resulted morphogenetic land scape architect and design. As such this tool and techniques were found very useful in understanding the landscape expression and geomorphology of the area. The satellite data image of IRS, MSS on 1:25000 and 1:50000 supplemented by Aerial Photograph with RF 1:50000 were used and field traverses in critical and crucial sections. The geomorphologial mapping was carried out both in field and laboratory, based on the image interpretation; the perceptual relief and geometry of the land form have how ever helped in differentiating various land form units in some cases. A megnoscopic is used for better viewing of image forms and accurate cartographic presentation. The prime objective of the study is was to analyze the geomorphic and morphtectonic elements, their spatial pattern and classification of discrete morph units to understand the morphological developments and stages of evolution of the area.

Remote sensing technique was utilized to analyze the geomorphology of the Sukta sub basin The basic data inputs is in the study from the LANDSAT - 4 MSS B/W bands 1,2,3,4 on 1:500,000 scale and standard mode FCCs of bands $1,2,3$ on $1: 250,000$ scale.

The geological and geomorphologic maps (on 1:1 million scales) as well as the physiographic map of National Atlas were consulted. Geomorphological analysis was carried out, following the standard methodology of visual image interpretation. The perceptual relief and geometry of the landforms has helped in differentiating the various geomorphic units.

The area studied forms the part of Narmada basin. It is drained by Sukta river and its tributaries. The Sukta rises from Satpura from the south east corner of area, at an elevation of about $500 \mathrm{~m}$ above m.s.l. The Satpura constitute upland of E-W trading hill ranges of Deccan basalt rising to an average height about $450 \mathrm{~m}$ above m.s.l. It forms the water divide between Narmada and Tapti basin. The area has been posed to renewed erosional and depositional activities and has been chiseled to various platforms surfaces and landform elements. Based on morphogenetic expression, elevation, drainage, pedogenetic characters, slope elements, land use pattern and diagnostics morphogenetic expression the area is divided into eight surfaces. These surfaces are both Quaternary terraces and Pre-Quaternary surfaces, the former are two surfaces of Sukta designated as ( $T_{-} 1$ to $T_{-} 2$ ) which are resultant product of Aggradations \& degradation of Quaternary sediment at an elevation of (280 to $300 \mathrm{~m}$ above m.s.l.) 
Morder surface (300 m above m.s.1.) Peneplantion Sarola Surface (320 m above m.s.l.) Peneplanation Khodar Surface (340 m above m.s.1.) Dissection \& Peneplanation Bargaon Surface (360 m above m.s.l.) Dissection / pedimentation / peneplanation Jalandar surface (400 m above m.s.l.) Peneplanation Sarai surface (440 m above m.s.1.) Peneplanation Gularpani Surface (SE) (460 m above m.s.1.) Peneplanation Gularpani Surface (SW) (460-80 $\mathrm{m}$ above m.s.1.). These surfaces are described here under. (Plate No_2)

\section{Quaternary Surfaces:-}

The Sukta river has formed two terraces besides its present day flood plain. These terraces are identified between elevations of 280 to $300 \mathrm{~m}$ above m.s.l. The occurrence of these terraces is restricted to Sukta and its meandering loop in the area. These represent the former levels of valley floors and were formed by cyclic rejuvenation of channel in recent past. These surfaces on Air photos are indentified by light to moderate grey tome, low drainage density, relict expression and agriculture land use pattern. The occurrences of river terraces between 280 to $300 \mathrm{~m}$ and rock cut terraces in same conformity am and elevation that the area is under compressive stress unstable.

The Quaternary landscaping the area of study is represented by of prominent stepped sequence of river terraces of fluvial origin which are well-developed in the Sukta valley. These terraces are both erosional and depositional in nature and are separated by linear and curvilinear scarp and represent former valley floor.

The Quaternary events of the Sukta portys two prominent terraces which are designated T_1 to T_2 besides T_0 in increasing order of antiquity. The terraces are described in detail separately. These are both erosional and depositional terraces and identified \& confined at an elevation of between $280 \mathrm{~m}$ to $300 \mathrm{~m}$ above $\mathrm{m} . \mathrm{s} .1$. The T_1 is being the youngest terrace andNT_2 it is being the oldest terrace identified in the valley. The occurrence of these terraces is restricted in Sukta its meandering loop and along the margin of valley. The occurrences of river terraces between 280 to $300 \mathrm{~m}$ and rock cut terraces in same conformity and elevation indicates that the area is under compressive stress and is unstable.

The other geomorphic features and landform elements delineated in the area are flood plain, point bar, low level terraces, channel braids, linear, scarp curvilinear scrap knee shaped band, scree re-retreating scrap and relict surfaces The various morph tectonic elements identified in the area are perennial channel segments, impersistent and partly internal drainage, knee shaped band, linear scarp \& rock cut terraces and rock scar which are the resultant elements of tectonic activity in area.

The salient and diagnostic elements of river terraces are incorporated in (Table No 2 _ to_6).

\section{Pre-Quaternary Surfaces:-}

The pre-quaternary surfaces are identified above the elevation of $300 \mathrm{~m}$ above m.s.l.on Deccan upland of Sapura. These surfaces are basically plantation surfaces, are developed in response to the tectonic up lift of the area and consequential adjustment of regional erosional cycle in the area during pre-quaternary times.

\section{Mondar Surface:-}

It is a pre-quaternary surface identified at an elevation of $300 \mathrm{~m}$ above m.s.l. and named after Mordar a prominent village, situated on this surface. It is covered by thick soil and is drained by Sukta and Lakhauri rivers. These streams display deep entrenchment, selective gullying along their courses and have chiseled rock cut terraces. The Lakhauri Nadi south of Mordar depicts perennial water channel segment which is anomalous and morphotectonic manifestation. It appears water table in the area is effluent in nature and tapped by channel along the NNE-SSW trending lineament. The slope of this surface is towards north east. On Air Photos it is characterized by distinct elevation low to moderate drainage density and agriculture land use pattern.

\section{Arola Surface:-}

It is a peniplain surface identified at an elevation of $300 \mathrm{~m}$ above m.s.l. and named after Sarola a prominent village situated at the nose of meandering loop of Sukta in the area. The surface has occupied large area between Rampura in North West and Nimkhera in the east. It is covered by thick soil and is drained by Sukta Lakhauri and their tributaries. It displays deep dissection and entrenchment along drainage. The slope of this surface is about 8-10 towards north east. On Air photos this surface is characterized by distinct elevation intensive dissection and selective and intensive gullying along NE-SW trending lineaments along the stream.

\section{Khodar Surface:-}

It is erosional surface delineated at an elevation of about $340 \mathrm{~m}$ above m.s.l. named after the Khodar a preminet village, situated on this surface. It has occupied large area between Rustampur in the east and Kumta in the west. It 
is drained by Sukta and its tributaries. It exhibit intensive dissection and entrenchment along Sukta river. The impersistent and partly internal drainage are seen on this surface around Jamthi, east of Piparahati, Jamli, Khurd and Pachama. This drainage diversely oriented and generally abuts against the lineament traversing the area. These are the positive imprints of Neatectonisam in the area. The density of these relict drainage a moderately high on the northern flank of Sukta river as compared to the south. It perhaps indicate that northern block is active and under the slow process of resettlements and relative re-adjustment. The NE-SW truanting lineament traversing along MotiNala cut across this surface from Sultanpur, south of Pachamba, Pawai Kalan, north of Takli Kalan, Khodar, Sarola and Ardalan kalan and beyong, appears to be active and some movements have been occurred along this element in recent past. It is also evident by the over all Neo-morgphogeneric manifestation of the area. The slope of this surface is about 8-10 towards north east. On Air photos this surface is characterized by distinct elevation, slope element intensive gullying selective land dissection and truncated relict drainage element.

\title{
Badgaon Surface:-
}

The Badgaon surface is identified at an elevation of $360 \mathrm{~m}$ and named after Borgaon a prominent village situated on this surface. It is erosional surface and was formed by the cumulative process of dissection pedimentation and peniplanation. It is widely developed and has occupied large area along the northern edge of Satpura between Bhilkheri and Sukhtanagar and between Suktanagar and Rustampur. It is drained by Sukta river and its tributaries. These streams are mostly sub-parallel to parallel and their courses are controlled by concealed fractures and lineament. The Sukta river display intensive entrenchment across this surface. It is associated with relict impersistant and partly internal drainage element. These are the signatures of Nectecanisam and are identified around Borgaon, west of Khirala, north of Khirala, and east and north east of Arud. These elements show some parallisam in their disposition and ENE-WSW trending lineaments. The Sukta river in the western part of this surface form the Knee shaped channel band and form the deep gorge of about $12 \mathrm{~m}$ bearing rock out terraces in the river bed. The intensive entrenchment along Sukta association of knee shape channel segment, rock terraces, relict internal drainage are the signatures of neoteconic activity. The prominent NE-SW trending lineament which traverse across the Sukta and other two E-W trending lineament north and south of Arud which about against Sukta lineament east of Piprahati appears to have been re-activated in recent past.

On Air photos this surface is delineated by distinct elevation truncated and hanging drainage land use pattern and diagnostic photo elements.

\begin{abstract}
Alandhar surface:-
It is situated at an elevation of about $400 \mathrm{~m}$ above m.s.l. and named after Jalandhar a prominent village located on this surface. It is developed along the northern edge of Satpura and its best development is seen around Jalandhar in the eastern part of the area. It is essentially a peniplain surface and forms a distinct plateau. It is drained by subparallel to parallel streams exhibiting intensive entrenchment along their courses which are controlled by concealed features and lineament. This surface bears segment of relict internal drainage, faulted scarp and demonstrate intensive linear gulling and accelerated headward erosion. These elements are imprints and signature of Neotectonism and suggest that the area is active. On Air photos it is characterized by distinct platform, elevation, drainage, land use practices and other diagnostic photo elements.
\end{abstract}

\section{Sarai surface:-}

It is a relict peniplain surface identified at an elevation of about $440 \mathrm{~m}$. above m.s.l. It forms distinct platform and separated by prominent curvilinear scarp. It is drained by sub-parallel stream which display accelerated headword erosion. On air photos it is delineated by elevation, relict characters and thick forest covers.

\section{Gularpani surface (se):-}

It is also a relict peniplain surface identified SE of Gularpani at an elevation of $460 \mathrm{~m}$ above m.s.l. It forms small plateau and separated by scarp on air photos it is identified by its elevation relict mode of occurrence, low to very low drainage density and forest cover.

\section{Gularpani surface (sw):-}

It is isolated erosional surface identified south west of Gularapani at an elevation of about 460-480 m above m.s.l. It forms small relict plateau separated by re-trearing scarp.(Plate No_2 \& Table No 2 to 6 ) 


\section{Tectonic setting of the area:-}

Narmada River originates at Amarkantak at an elevation of about $1057 \mathrm{~m}$ above m.s.l. descended from the mountainous tract traversing over a distance of $1280 \mathrm{~km}$ across the middle of the Indian sub-continent to join the Gulf of Cambay, near Baroda in Gujarat state. The river course of Narmada is conspicuously straight, controlled by E-W lineament. It descends down the mountainous tract through deep and steep gorges in straight sinuous to meandering pattern with average sinuosity index of 1.38, which at places exceeds 1.55 for some selected segments of Narmada channel. It almost flows E-W along the Lineament over a length of 1300 Kilometers across the middle of Indian sub-continent to debouch into the Gulf of Cambay in the Arabian sea. It is bound by Vindhyachal in the north and Satpura range to the south; the area in between these two upland is found to be ideal loci for a study of Quaternary sedimentation, as witnessed by the presence of multicyclic sequence of Quaternary terraces in the valley. These terraces represent the former levels of valley floors formed by cumulative erosional and depositional activities of the river system.

The area studied forms part of SONATA LINEAMENT ZONE which tectonically encompasses two crustal provinces of Central India Shield, namely, the Northern Crustal Province (NCP) and the Southern Crustal Province (SCP (Acharyya and Roy, 1998; Roy, 1988). The two provinces are separated by a crustal level shear zone, referred as Central Indian Suture (CIS Jain et al. 1995). The southern part of the NCP, containing the Satpura and son Narmada (SONA) valley geographic domain, is known as Central Indian Tectonic Zone (CITZ; Radhakrishna and the CITZ are marked by Narmada North Fault (NNF) in the north and CIS in the south (Acharyya, 1999). The Jabalpur earthquake affected area lies in SONA lineament zone which forms the northern units of CITZ. The SONA zone is about $1600 \mathrm{~km}$ long and $150 \mathrm{~km}-200 \mathrm{~km}$ wide, extending from the southern margin of Kathiawar peninsula in the west to the margin of Vindhyan basin in the east (Crewford, 1978: Ahmad, 1964). The zone has been a major locus of episodic tectonism with evidences of reactivation. The E-W to ENE-WSW trending Narmada and Tapti lineament from a prominent tectonic belt (SONATA) in midplate continental India 2). Narmada tectonic line and its presumed eastward extension, Son, have been considered as a major Precambrian deep crustal features (Auden, 1949; West 1962) and possibly a palaeo-rift (Nayak 1990) extending hundreds of kilometer in E-W direction (Mishra 1987, 1992). Pascoe (1959) recognized the Narmada lineament as a rift at its western ends however, its eastward extension and the relative timing of the Narmada rifting and Daccan Trap eruption remained unknown. The correlation of structure and geo-physical data shows that the Son-Narmada and Tapti lineament together represent an interpolate rift with a central (Satpura Block) horst bounded on either side by grabens: the Narmada graben on the north and the Tapti graben to the south (Mishra et al, 1999).

The Narmada Rift valley is conspicuous ENE-WSW to E-W trending prominent composite structural system across Indian sub-continent. It consists of various blocks which are dislocated and faulted along various faults and lineaments in space and time. The Narmada Rift System consists of various sub- basins like Hiran , Sher Shakkar, Dudhi,Tawa, in eastern and central segment, where as in the western extension Sukta which are minor basins are integrated and in built part of main rift System. These sub basins possess imprints of rinsing sinking and rifting events. These imprints are recorded in terms of manifestation and signature on landscape, drainage, of land form elements, present and paleomeandering signature, river terraces, cut of meanders, paleo channels, scars, rock cut terraces, entrenchment and linear and curvilinear scars. These sub basins have developed transverse to the main axis of Narmada rifting and had deep cut across the quaternary blanket. The evolution of Narmada graben is differential and asymmetrical with rinsing and sinking valley floor. In Sukta sub basin a prominent NW-SE trending lineament is identified which controlles the course of Sukta, it is named as Sukta lineament. It traverses from Katra in the east to Mordar in the north west over the distance of about $45 \mathrm{~km}$. It appears to be basement element and some movement has taken place along this lineament in recent to Segwal in about $19 \mathrm{~km}$. in length, the upper segment of Lakhauri Nadi between Kumtha and Gandhwa, is controlled by this lineament. It beyond Gandhwa cut across Sukta and Itwa lineament north of Badgaon and about against NE-SW lineament south of Segwal. This lineament bears the signature of neotectonism as disclosed by morphogenetic setting of the area. Another NW-SE trending lineament east of khodar deeply incised Sarala surface and traverse across the Sukta lineament and trunkets against the Moti-Nala along knee shape channel band of Sukta.The Sukta lineament is an active lineament as manifested by neosiesmic signature as displayed in the area. The area is unstable prone to earthquake. (Plate_1, 2, 3, 4 \&5) 


\section{Lineament Febrics:-}

The study revealed that the area embraces number of major, minor lineament fracture and faults. Though they have been noted in varying length and in a number of directions, only the more prominent ones which are persistent are grouped and discussed. Accordingly, four major lineament patterns have been identified and discussed. These lineament patterns viz i) NE-SW ii) NW-SE, iii) NNE-SSW to N-S, iv) NNW-SSS to N-S, v) ENE-WSW to E-W. The relative percentage of occurrence of lineament in these different patterns is $29.7 \%, 23.4 \%, 14.1 \%, 9.4 \%$ respectively. The analysis of these linear elements reveal that mega and intermediate lineament exhibit anisotropic intensity and minor lineament, fractures and faults isotropic intensity. (Plate (Plate _1, 2, 3, 4 \& 5, 6)

\section{Ne-Sw Lineaments:-}

This set of lineament is very conspicuous and stretch across the entire length of northern part of the area. It consists of about 19 lineaments which is $29.7 \%$ of total lineament present in the area. The length of these lineaments varies from 25 to $25 \mathrm{~cm}$ and the average length is about $7.5 \mathrm{~km}$. A prominent NW-SE trending lineament which is controlled by the course of Sukta and named as Sukta lineament. It traverses from Katra in the east to Mordar in the North West over the distance of about $45 \mathrm{~km}$. It appears to be basement element and some movement has taken place along this lineament in recent to Segwal in about $19 \mathrm{~km}$. in length, the upper segement of Lakhauri Nadi between Kumtha and Gandhwa, is controlled by this lineament. It beyond Gandhwa cut across Sukta and Itwa lineament north of Badgaon and about against NE-SW lineament south of Segwal. This lineament bears the signature of neotectonism as disclosed by morphogenetic setting of the area. Another NW-SE trending lineament east of khodar deeply linaised Sarala surface and traverse across the Sukta lineament and trunkets against the MatiNala along knee shap channel band of Sukta.

In the Satpura upland south of Gullarpani three prominent NW-SE trending lineaments are delineated and named as Dahi, Mandwa, and Amadnagar lineament. These lineaments cut across about $190 \mathrm{~m}$ thick piles of basaltic lava sheets and seem to be active in recent past as witnessed by the geomorphic setting, drainage, intensive gullying, selective entrenchment, re-treting scarp and alignment of isolated relict surface in the area.

\section{Nnw-Sse To N-S Lineament:-}

It includes 15 lineaments which constitute $23.4 \%$ of the total lineament traversing the area. The length of these elements varies from 2.5 to $10 \mathrm{~km}$ and average length is about $4.5 \mathrm{~km}$. These elements are generally associated with master joints and fractures and seem to be transverse nature and conspicuously associated along the northern edge of Satpura upland with the Badgaon surface.

\section{Nne-Ssw To N-S Lineament:-}

This group of lineament constitutes about $4.1 \%$ of total lineament of the area. The relative length of these lineaments is comparatively less than the other group it varies from 2 ro $6.5 \mathrm{~km}$ and average length is about $3.25 \mathrm{~km}$. These are associated with master joints and fractures of the area. These elements are coupled with the contemporary NNWSSE lineament and are developed in response to resultant stress and strain caused by major events.

\section{Ene-Wsw To E-W Lineament :-}

This group includes six lineaments which constitute about $9.4 \%$ of total lineament traversing the area. The length of these linear elements varies from 1.5 to $6 \mathrm{~km}$ and average length is about $3 \mathrm{kms}$. These lineaments east of Arud bear the imprints of Neotectonism.

\section{Neotectonism:}

The area studied is part of Narmada basin and is drained by Sukta and its tributaries. The Sukta rises from the Satpura at are elevation of about $500 \mathrm{~m}$ above m.s.l. It decends northerly in straight to sinuous channel pattern across the deep gorges of Satpura ranges and debauches in the plain east of Katra. The river takes sharp turn towards north west of Sukta Nagar and flows towards north east accorss the central part of the area and joins Chowta Tawa river around Rudhi. The other important tribularies drain the area is Bham, Lakhauri and Abna river.In the area the course of Sukta river has been controlled by NE-SW trending lineament which bears imprints of neotectonism. These imprints are of cyclic nature and are well documented in the erosional and depositional domain of Sukta. The signature of these neo-seismic activities is also displayed in over all morphogenetic expression of the area. The Sukta river is associated with several nectectonic and morphotectonic elements, like straight channel segment, flood 
plain quaternary terraces, entrenched river bank, knee shaped bands, rock cut terraces, linear scrap perennial channel segments, and truncated hanging drainage.

The present flood plain of Sukta river is confined in the narrow valley along the river course. This flood plain occurs at the elevation between 265 to $280 \mathrm{~m}$ above m.s.l. and has entrenched its bank about $12 \mathrm{~m}$. The deeply selective and incised entrencher nature of the channel suggests rejuvenation of the river due to re-activation of NE-SW trending lineament towards the later phases of quaternary sedimentation. The relict quaternary terraces associated with the meandering loops and entrenched valley is indentified at an elevation of 340-370 m about m.s.l. These are the former level of valley floor of Sukta and were formed by cyclic rejuvenation of channel twice in the recent past. It indicates at least two distinct sequential phases of neotectonic activity along NE-SW trending lineament during Holocene time.

The Sukta river is associated with knee shaped channel band around Sarala. It is bounded by ENE-WSW trending lineament in south and NW-SE trending lineament in east and west respectively. The northern and southern lineaments converge in the east around Badgaon. The disposition of this knee shaped band with respect to the quaternary terraces, entrenched valley and frame work of lineament indicate Neosiesmic activity along these lineaments in the area.

The Sukta is associated with prominent rock cut terraces/rock benches east and northeast of Sukta Nagar, east of Khairala, around Piprahati, north of Badgaon. These elements indicate anomalous high kinetic energy condition of channel system towards later phases of sedimentation. It is perhaps due to re-activation of NE-SW trending lineament in recent past.

The linear scarp is one of prominent element associated with Sukta river. These are essentially incision scarp and their total length is about $22 \mathrm{~km}$. The height rises from 5 to $15 \mathrm{~m}$ and average height is about $12 \mathrm{~m}$. These are cyclic scarp and display divergent relative disposition all along the channel it reveal that the channel has suddenly readjusted its base level cutting across the bed rock perhaps due to re-activation Sukta lineament in recent past.

The Sukta all along its length of $32 \mathrm{~km}$ in the area display its dry river course except perennial segments of channel pool around Badgoan. This erratic behavior of stream suggest its influent nature in the area perhaps due to concealed controlled of NW-SE trending lineament, which ease out its water to sub-surface water regime.

The perennial segment of channel around Badgaon exhibit reveral behavior of stream revealing effluent nature of water table due to interesting of NW-SE and NNE-SSE trending lineament around Badgaon.

The area north of Sukta Nagar display impersistent, partly internal and truncated drainage. It is seen around Arud, north west and south of Sultanpur south west of Rustampur east of Jamli khurd around Pawaikalan, north of Takli Kalan and around Shaikhpura. These drainage are diversely distributed and often truncated against the lineament traversing the area.

It indicates re-adjustment of base level of drainage, in the response to the recent movement along the network of lineaments traversing the area. It is interesting to note that these drainage elements are mostly confined north of Sukta river. It indicates that northern block is more active and under the slow process of re-adjustment as compared to other blocks (Plate_2, 3, 4)

\section{Summary Conclusion And Recommendataions:-}

The geological, geomorphological and Neotectonic studies of parts of Sukta sub basin in parts of Khandwa district Madhya Pradesh were carried out with the aid of Satellite Imagery (IRS), air photos in Survey of India sheet 55 C /6 to acquired and accrued the data from optical signatures of micro neosiesmic episodes and recent movements along the lineament fabrics of Earthquake prone area. The Geomorphologic keys and morphotectonic manifestation in the west central segments of the SONATA LIEAMET ZONE are applied to trace and delineate imprints of neotectonism. The results of data synthesis, analysis of imprints and signature and modeling of the area by computer has been documented $\&$ presented for the first time.

The study reveals that geologically the area is occupied by Deccan trap and Quaternary sediments. The Deccan Trap complex consists of fifteen basaltic lava flows identified between 250 to $600 \mathrm{~m}$ above m.s.l. These lava flows are grey in color, moderately to highly vesicular in nature and each is separated by red bole intertrappean beds or mega 
cryst unit. These lava flows are divided in to two formations viz i) Khandwa formation (Nimar Group) consisting of six flows between elevation of 250-360 m) and Asirgarh formation (Satpura Group) consisting of nine flows between 360-600 m above m.s.l. The exposed thickness of these flows is about $190 \mathrm{~m}$.

Plate No_2:- Geomorphologic Map of Parts of East Nimar District, M.P.

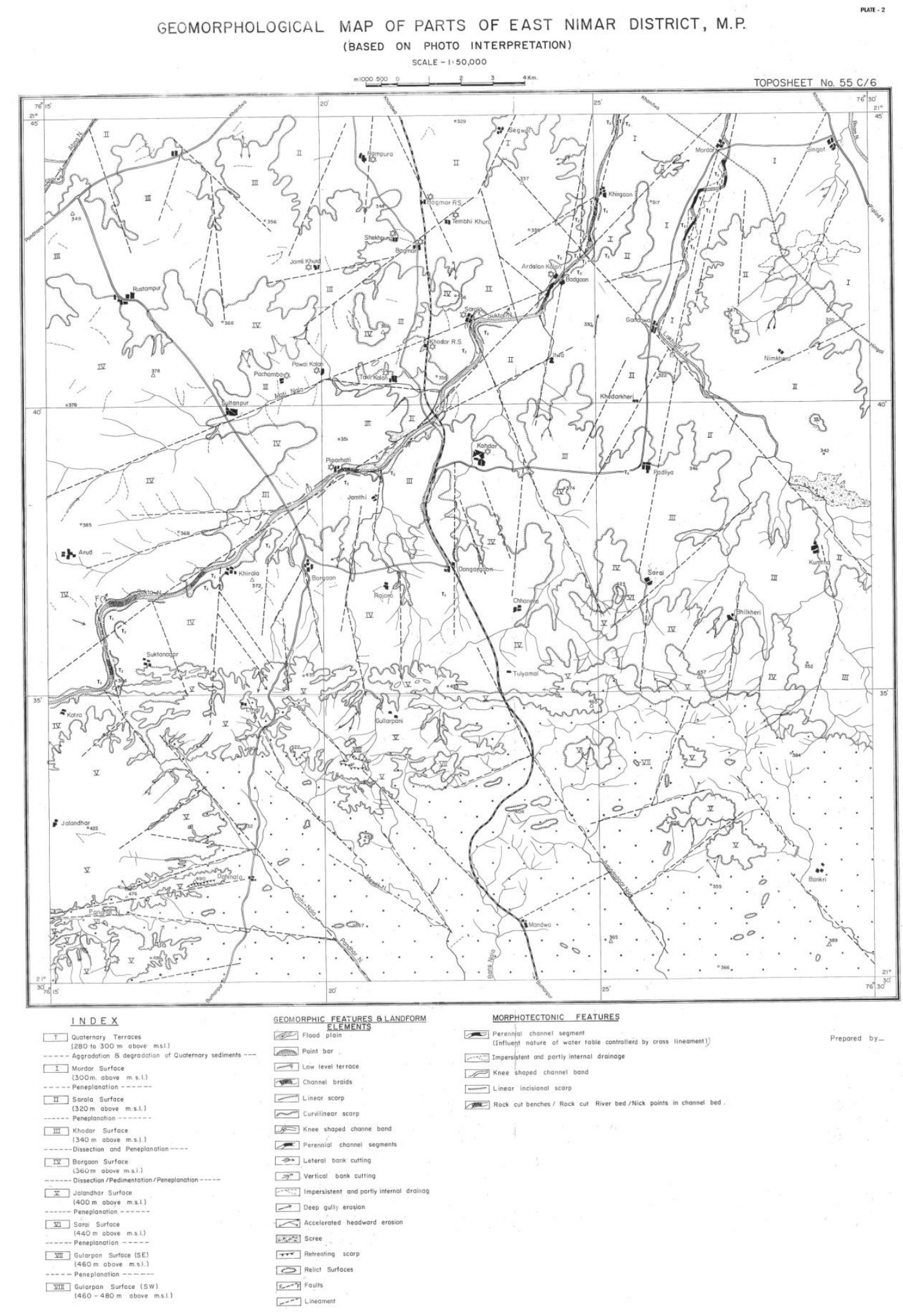




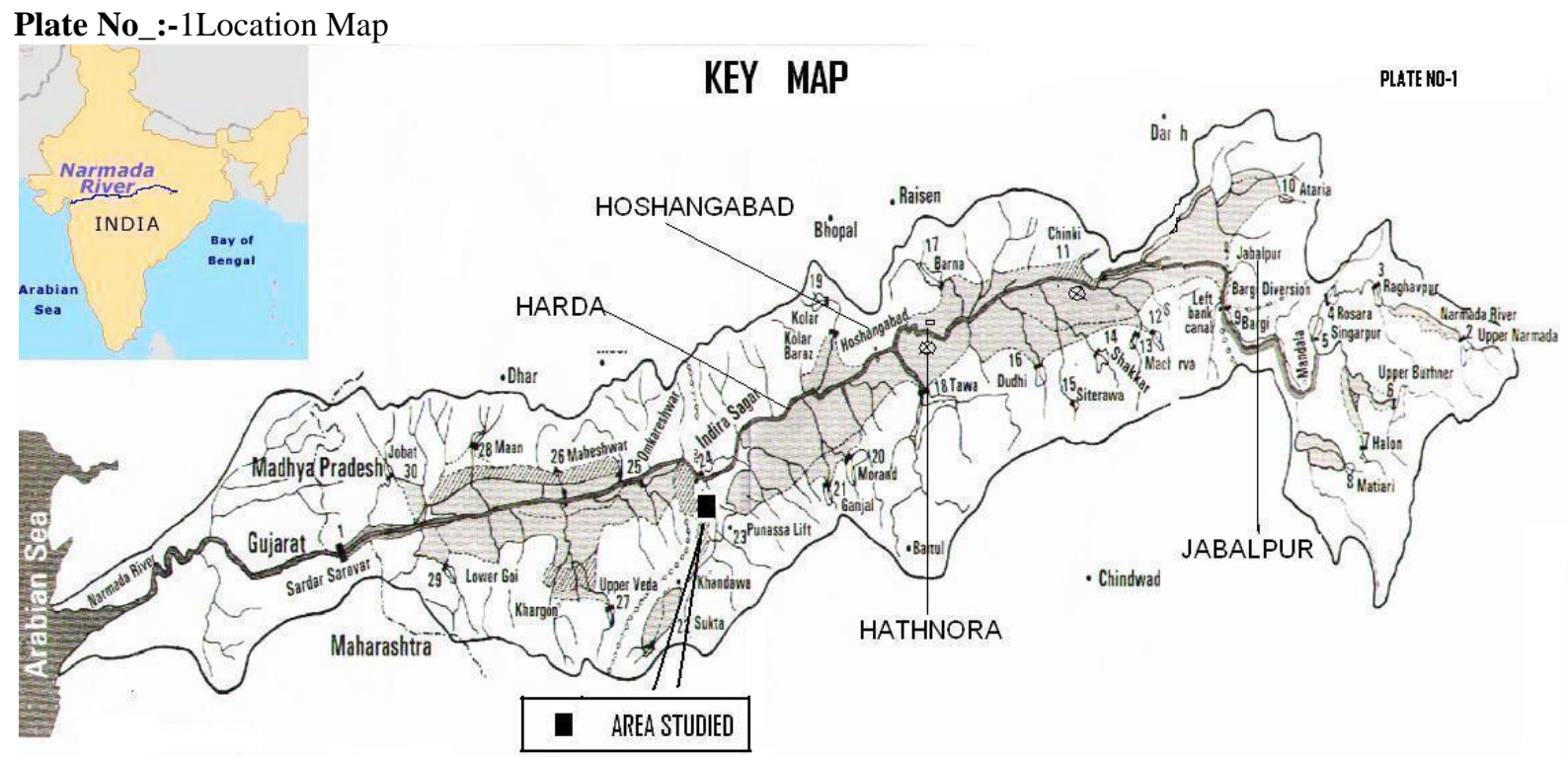

Plate No_6:- Intensity of lineament Topo Sheet No. 55C/6 List of Plates

\section{INTENSITY OF LINEAMENT TOPOSHEET $-55 \mathrm{C} / 6$}

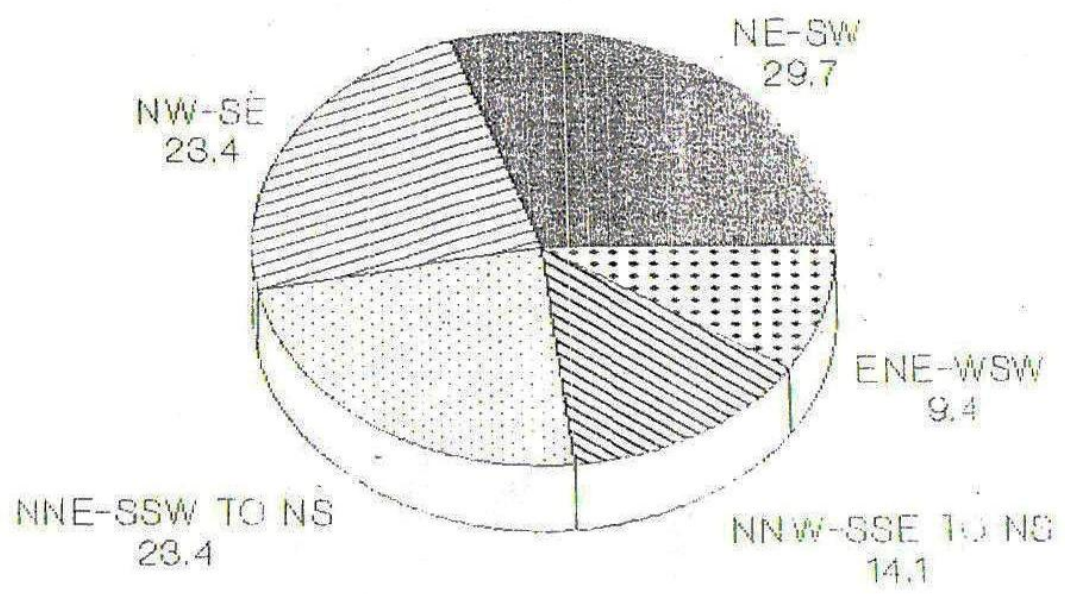


Plate No_5:- 3_D Diagram of 55C /6 Khandwa District M.P India.

PLATE- 5

\section{3-D PROJECTION ON OF 55C/6, KHANDWA DIST. (M.P.) INDIA}

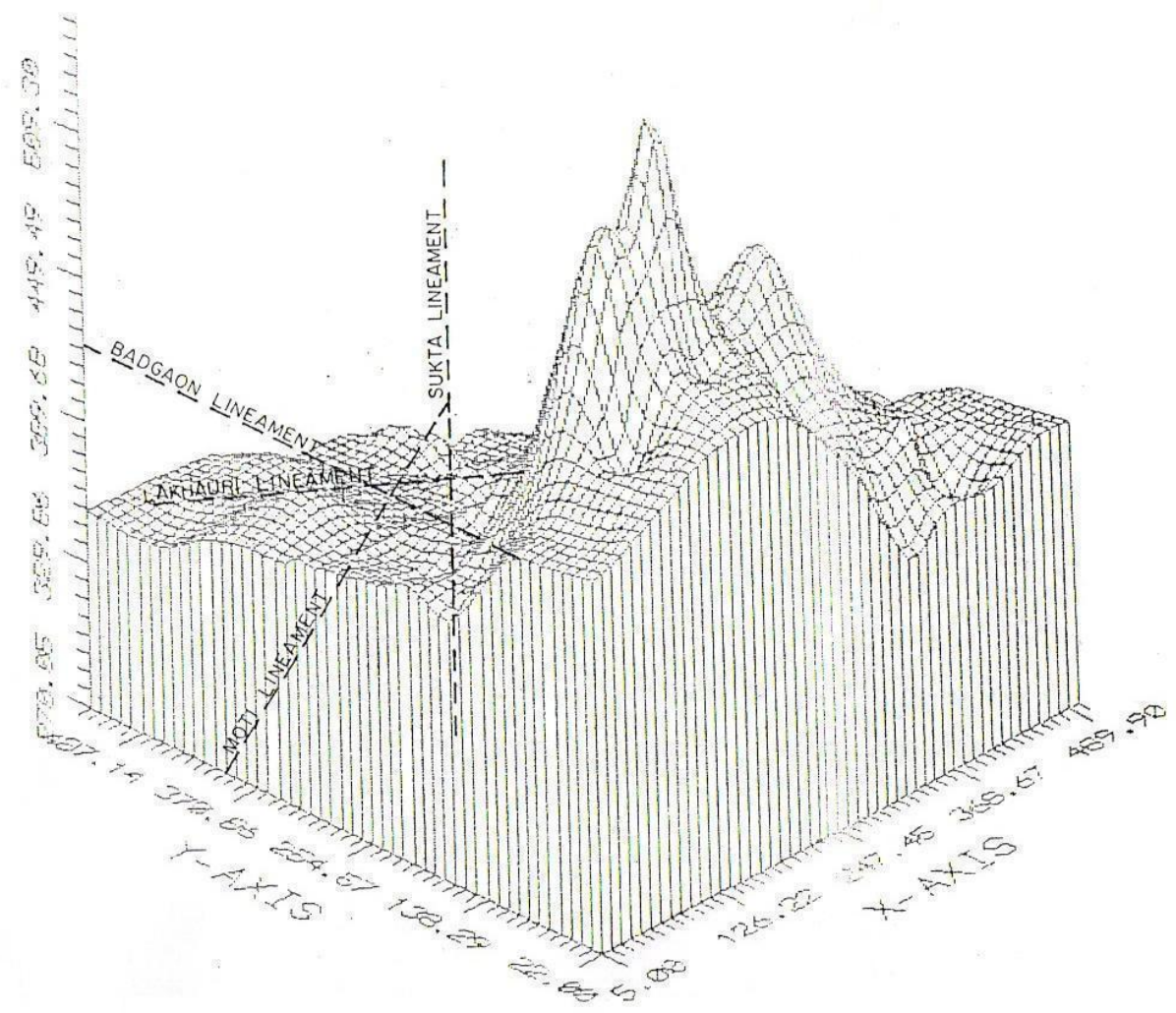


Plate No_3:- Geodetic Map of 55 C/6 Khandwa District M.P. India

PLATE - 3

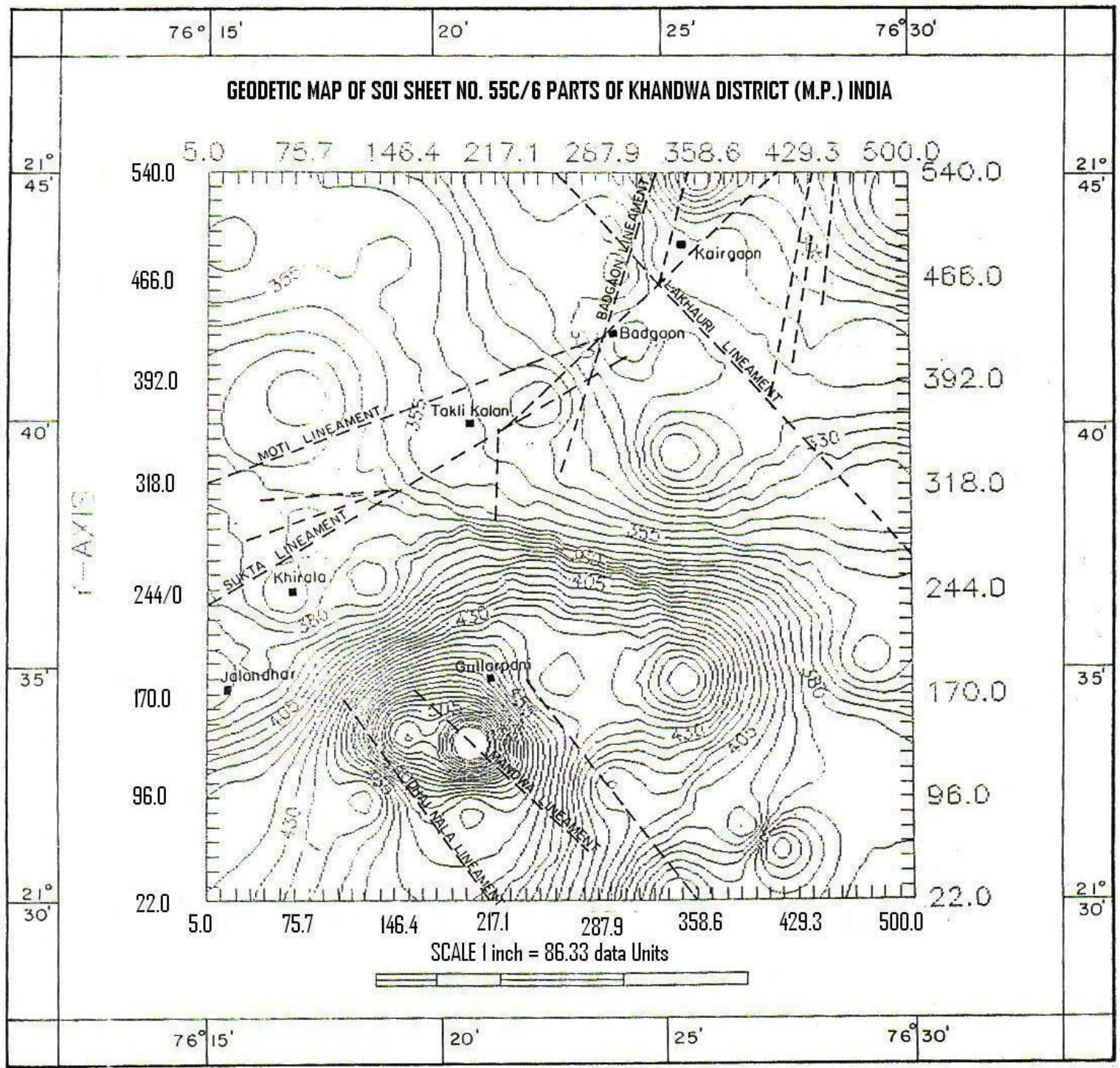


Plate No_4:- Fabrics of Sukta Lineament District Khandwa M.P.India

\section{PLATE-4}

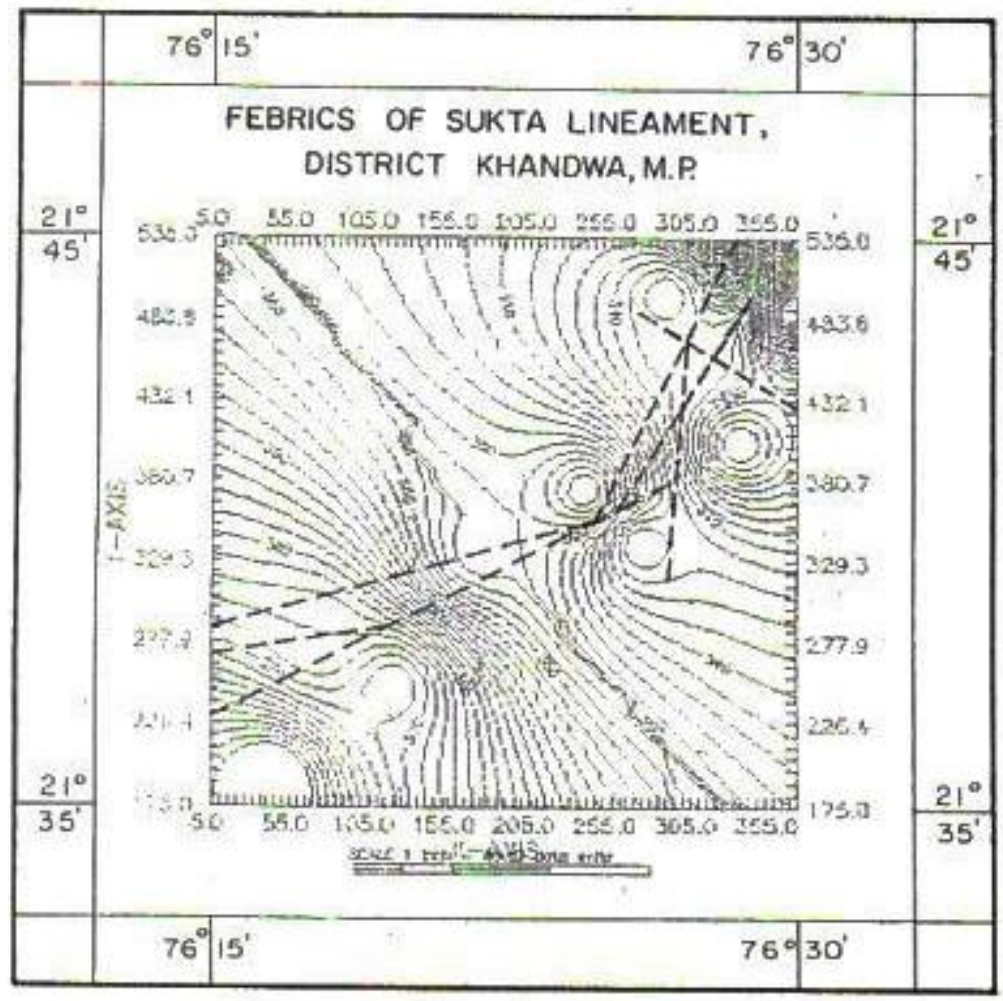

\section{3-D PROJECTION ON OF 55C/6. KHANDWA DIST. (M.P.) INDIA}

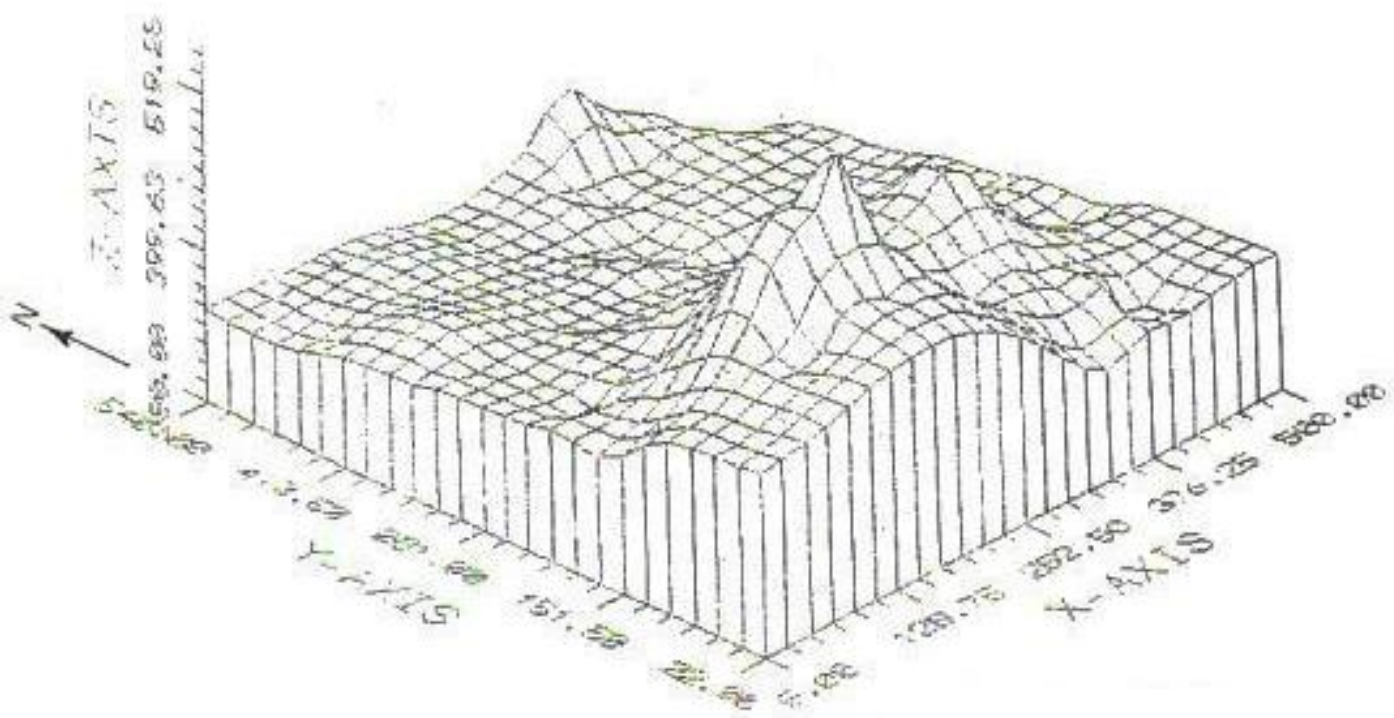


The Quaternary deposits are represented by the sediment of two domains viz. The sediment of present domain of Sukta and sediment of palceo-domain of Sukta. These sediments are represented by sand, silt, clay and rock gravels. The average exposed thickness of these deposits is about $3 \mathrm{~m}$.

Geomorphologically, the area comprised of nine surfaces each surfaces is characterized by district morphogenetic expression, drainage, pedogenetic character slope elements and land use practices. These surfaces are identified between 280 to $480 \mathrm{~m}$ above m.s.l. These surfaces delineated in increasing antiquity are Quaternary terraces (280 to $300 \mathrm{~m})$, Modar surface $(300 \mathrm{~m})$, Sarola surface $(320 \mathrm{~m})$, Khodar surface $(340 \mathrm{~m})$, Bargaon surface $(360 \mathrm{~m})$, Sarai surface (940m), Gularpani (SE) (460 m) and Gularpani (SW) (460 m). These surfaces bear imprints of Neotectonism in the area. Besides geomorphic landforms elements and features delineated in the area are flood plain, point bar, low level terraces, channel braids, linear scarp and relict terraces. The Morphotectonic elements are perennial channel segments, impersistent and partly internal drainage, knee shaped channel bend linear scarp and rock cut terraces.(Plate No._2)

The area embraces five sets of lineament viz i) NE-SW lineament, ii) NW-SE lineament, iii) NNE-SSW to N-S lineament, iv) NNW-SSE to N-S lineament, and v) ENE-WSW to E-W lineaments. The relative percentage density of occurrence of these elements in different categories is $29.7 \%, 23.4 \%, 23.4 \%, 14.1 \%$ and $9.4 \%$ respectively. The analysis of relative intensity of these indicate that major intermediate lineament exhibit anisotropic intensity and minor lineament isotropic intensity. (Plate No._6)

The Sukta is the major stream which drains across the northern part of the area. Its course is controlled by NE-SW trending lineament named as Sukta lineament. It is a basement fracture and has imprints of its re-activation all along the course of Sukta river. It is also evident by the channel morphology, morphotectonic manifestation and relative disposition of various geomorphic elements and their inter relation with these lineament.

The Lakhauri NW-SE trending lineament also bears some imprints of Neotectonism and suggests some movement in the area.

The NNW-SSE to N-S, NNE-SSW to N-S lineaments are generally associated with master joints and fractures, their depth persistently is erratic and shallow and they are devoid of any significant signature of Neotectonism.

The ENE-SSE to E-W trending lineament ara parallel to Narmada lineament zone constitute about $9.4 \%$ of total lineament density. This lineament bears imprints and signature of Neotectonism east of Arud.

The study of various aspects as discussed above indicate that Neotectonically the areas is active and some movements have taken place along NE-SW, NW-SE and ENE-WSW to E-W trending lineament in the area in recent past. The movement along this lineament may be responsible far recent tremors in the area; it appears that $t$ is tectonically active and prone to Neo-seismic movements..

\section{Reference:-}

1. Sharma R.K. \& Yadova N.L. (1985). Geology in parts of Khandwa district M.P., unpublished report Geological Survey of India.

2. Yadova N.L. \& Kandpal G.C. A report on systematic Geological mapping of Deccan trap complex in south eastern part of Khandwa district M.P. unpublished report Geological Survey of India. 